\title{
SILICON NITRIDE - MOLYBDENUM CUTTING TOOLS FOR CAST IRON MACHINING
}

\section{NARZĘDZIA SKRAWAJĄCE Z AZOTKU KRZEMU-MOLIBDENU DO OBRÓBKI ŻELIWA}

\author{
Kamil BRONISZEWSKI ${ }^{1}$, Jarosław WOŹNIAK ${ }^{1}$, Mateusz PETRUS ${ }^{1}$, \\ Kazimierz CZECHOWSKI ${ }^{2}$, Lucyna JAWORSKA ${ }^{2}$, Andrzej OLSZYNA ${ }^{1}$
}

Abstract: This article presents the result of the study of the properties of silicon nitridemolybdenum cutting tools. It describes the technological process of manufacturing composites with the use of Spark Plasma Sintering as the consolidation method. Obtained composites are characterized with high relative density and high values of Vickers hardness and fracture toughness. Dry machining tests performed on cast iron (ACO Eurobar GG FP) shows that produced cutting tools are characterized with good cutting performance comparable with commercial cutting tool. $\mathrm{Si}_{3} \mathrm{~N}_{4}$ cutting tool edges wear uniformly without cracking or chipping.

Keywords: silicon-nitride-molybdenum cutting tool, consolidation method, SPS, cast iron machining, dry machining, cutting performance

Streszczenie: Artykuł prezentuje proces technologiczny wytwarzania ostrzy skrawających na osnowie azotku krzemu $\mathrm{z}$ dodatkiem molibdenu oraz wyniki badań ich podstawowych właściwości. Konsolidacja mieszanin proszkowych została przeprowadzona z wykorzystaniem metody Spark Plasma Sintering (SPS). Otrzymane kompozyty charakteryzują się wysoką gęstością względną oraz wysokimi wartościami twardości Vickersa i odporności na kruche pękanie. Przeprowadzone próby skrawania na sucho żeliwa (ACO Eurobar GG FP) wykazały, że wytworzone ostrza skrawające charakteryzują się wysoką wartością czasu życia ostrza, a ich zużycie przebiega w sposób równomierny bez widocznych pęknięć i wykruszeń.

Słowa kluczowe: narzędzie z azotku krzemu-molibdenu, konsolidacja, SPS, obróbka żeliwa, obróbka na sucho, wydajność skrawania

\footnotetext{
${ }^{1}$ Warsaw University of Technology, Faculty of Materials Science and Engineering, ul. Wołoska 141, 02-507 Warsaw, Poland

${ }^{2}$ The Institute of Advanced Manufacturing Technology, ul.Wrocławska 37a, 30-011 Krakow, Poland
} 


\section{INTRODUCTION}

Ceramic materials are characterized with unique set of properties sought in many applications. The most important are high hardness, high temperature strength, low density, wear resistance and good chemical and corrosion resistance. It allows ceramics to be used as thermal barriers, wear plates, gears, bearings, high-stiffness spindles etc. Ceramic materials of course are characterized with many more interesting properties what makes them important materials in almost every branch of industry: aerospace, automotive, medical, military, communication, consumer uses $[1,3,5,6,8]$.

Mentioned above properties of ceramic materials are also very desirable in cutting tools industry. Their ability to work with high cutting speed and without cutting fluids are great assets that can increase efficiency of production and also decrease the costs of produced details. The main drawback of ceramic is the brittleness which makes a critical wear of ceramic cutting tools to occur in the form of cracking or chipping. Unpredictable time of cutting edges cracking is unacceptable in machining process. Among ceramic materials silicon nitride is characterized with relatively high fracture toughness, high hardness, good wear and chemical resistance what makes this material a very promising matrix of a composites for cutting tools [7]. Further increasing fracture toughness can be achieved by introducing a metal phase to a silicon nitride matrix. Of course it means a decrease of hardness and chemical resistance of such composite compared with pure $\mathrm{Si}_{3} \mathrm{~N}_{4}$ sinter but addition of metal can enhance cutting performance in another interesting way. In previous article authors described a self lubricating properties of alumina-molybdenum composite for cutting tools [2]. Thermal oxidation of molybdenum during machining process leads to creating a thin layer of $\mathrm{MoO}_{3}$ oxides that acts like a solid lubricants decreasing friction coefficient and therefore increasing cutting tool life. This article focuses on silicon nitride matrix composites with addition of various amount of molybdenum phase intended for cutting tools.

\section{EXPERIMENT}

Powder substrates used in this work were commercial silicon nitride powder (H.C. Starck, chemical purity of $99.9 \%$ ) and commercial molybdenum powder (H.C. Starck, chemical purity of $99.6 \%$ ). Silicon nitride is a material difficult to sinter and to obtain a high density samples the addition of $\mathrm{MgO}$ and $\mathrm{Y}_{2} \mathrm{O}_{3}$ phases was necessary. Those phases creates a glass phase during sintering the silicon nitride what facilitate whole sintering process and allow to produce high density sinters. The silicon nitride with addition of zirconia and magnesium oxides were wet blended with the use attritor type mill. After drying molybdenum powder was added and powder mixtures were prepared with the use of planetary type mill and dried. Final consolidation of powder mixtures was carried out with the use of SPS (Spark Plasma Sintering) method: $\mathrm{T}=1650^{\circ} \mathrm{C}, \mathrm{t}=5 \mathrm{~min}$., Argon atmosphere. The produced composites were characterized with three different weight content of molybdenum: 5\%, $10 \%$ and $15 \%$. Pure silicon nitride samples were produced to examine influence of molybdenum addition on mechanical properties of sinters. After grinding and polishing of sinters a basic mechanical properties were examined.

Density of samples were examined with the use of a helium pycnometer (Ultrapycnometer 1000). Hardness and fracture toughness were measured with a Vickers Hardness Tester (FV- 
700e.) with the use of the indentation method under the load of $196.2 \mathrm{~N}$. The equation of Niihara, Morena, Hasselman was used to calculate $\mathrm{K}_{\mathrm{IC}}$ coefficient:

$$
\mathrm{K}_{\mathrm{IC}}=0.0711\left(H_{V} a^{1 / 2}\right)\left(E / H_{V}\right)^{2 / 5}(c / a)^{-3 / 2}
$$

Young modulus of composites was measured with the use of the ultrasonic method (Optel refractometer). The microstructure observation was performed on an optic microscope (Nikon Eclipse MA200) and the average particle size was determined by a computer program (MicroMeter). Cutting tools of square cross-section were manufactured and then some dry machining tests followed. The tests were performed with the use of a CNC machine (TR90B). Two different machined materials were used: cast iron GG FP ACO Eurobar (hardness 170-181 HB) and hardened 145 CR6 steel (hardness $50 \pm 2$ HRC).

Machining tests parameters were the following: (cast iron) cutting speed $V_{c}-400 \mathrm{~m} / \mathrm{min}$, cutting feed $f-0.10 \mathrm{~mm} /$ rot., cutting depth $a_{p}-0.5 \mathrm{~mm}$, (hardened steel) cutting speed $V_{c}-$ $200 \mathrm{~m} / \mathrm{min}$., cutting feed $f-0.17 \mathrm{~mm} /$ rot., cutting depth $a_{p}-0.5 \mathrm{~mm}$.

The wear of tool was defined by a flank wear $V B_{C}=0.3 \mathrm{~mm}$ parameter (according to the PNISO 3685:1996). After conducting machining tests the surface roughness parameter $R a$ was measured with the use of a profilometer (Hommel Tester T1000E). The machining tests results were compared with that of a commercial ceramic composite cutting tool.

\section{RESULTS}

Composites produced with the above mentioned method are characterized with high relative density (over $98.4 \%$ ). With the increase of molybdenum content a slight increase in density may be observed (Fig. 1).

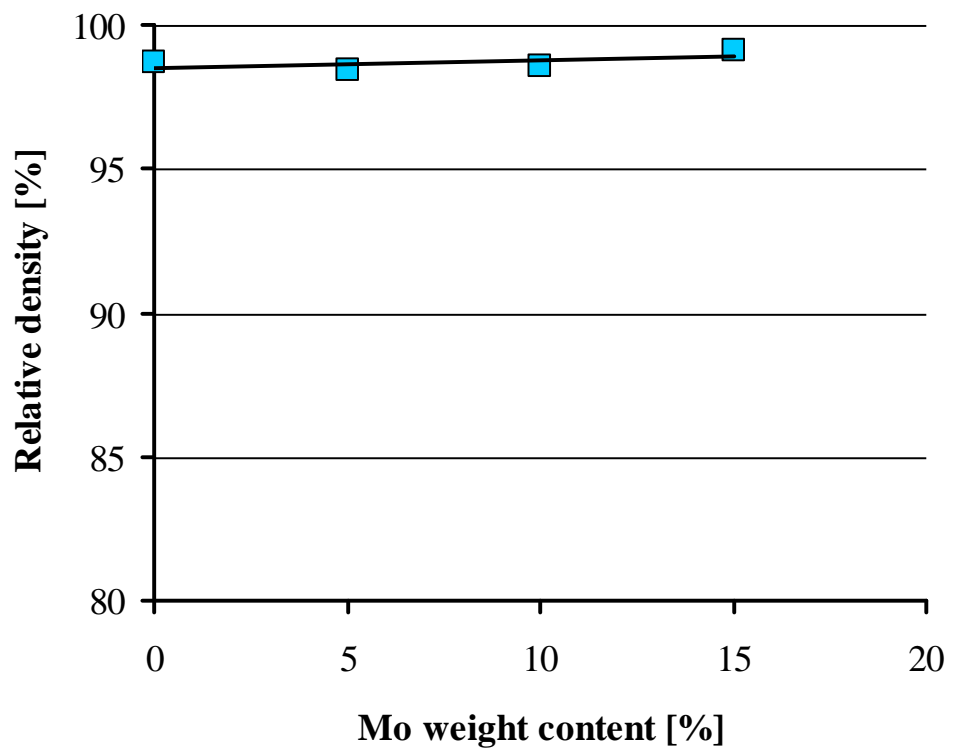

Figure 1. Relative density results for produced $\mathrm{Si}_{3} \mathrm{~N}_{4}-\mathrm{X} \%$ wt. Mo composites 


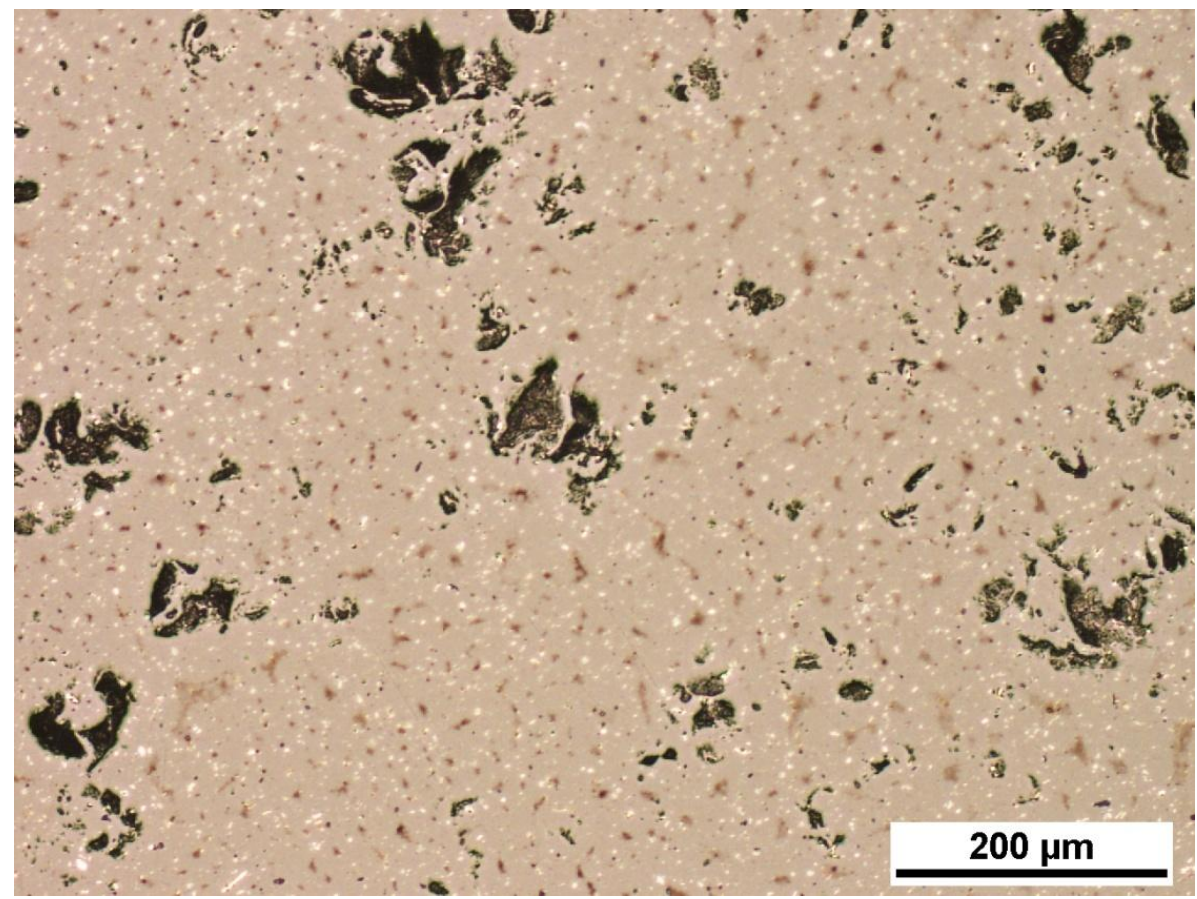

Figure 2. The microstructure of $\mathrm{Si}_{3} \mathrm{~N}_{4}-5 \%$ wt. Mo

The microstructure of produced composites reveals the presence of fine isometric particles (bright ones) which are the molybdenum particles and much larger with irregular shape (darker ones) which are believed to be molybdenum silicides particles created during sintering process [4,9]. Increasing the content of molybdenum causes increase in average particles size of molybdenum (Table 1). Nonetheless the high values of standard deviation must be taken into account due to the fact that increase of average $d_{2}$ parameter of molybdenum particles is not big and several times lower than standard deviation. However it is very likely that agglomeration effect took place in technological process of preparing silicon nitride - molybdenum composites what is reflected in higher values of average size of Mo particles for composites with the higher Mo weight content.

Table 1. Average molybdenum particles size $\overline{d_{2}}$ and coefficient of variation $\operatorname{CV}\left(d_{2}\right)$ of produced $\mathrm{Si}_{3} \mathrm{~N}_{4}-\mathrm{X} \%$ wt. Mo composites

\begin{tabular}{|c|c|c|c|}
\hline Weight content of Mo [\%] & 5 & 10 & 15 \\
\hline$\overline{d_{2}}[\mu \mathrm{m}]$ & 0.93 & 0.95 & 1.05 \\
\hline $\operatorname{CV}\left(d_{2}\right)$ & 0.59 & 0.63 & 0.69 \\
\hline
\end{tabular}




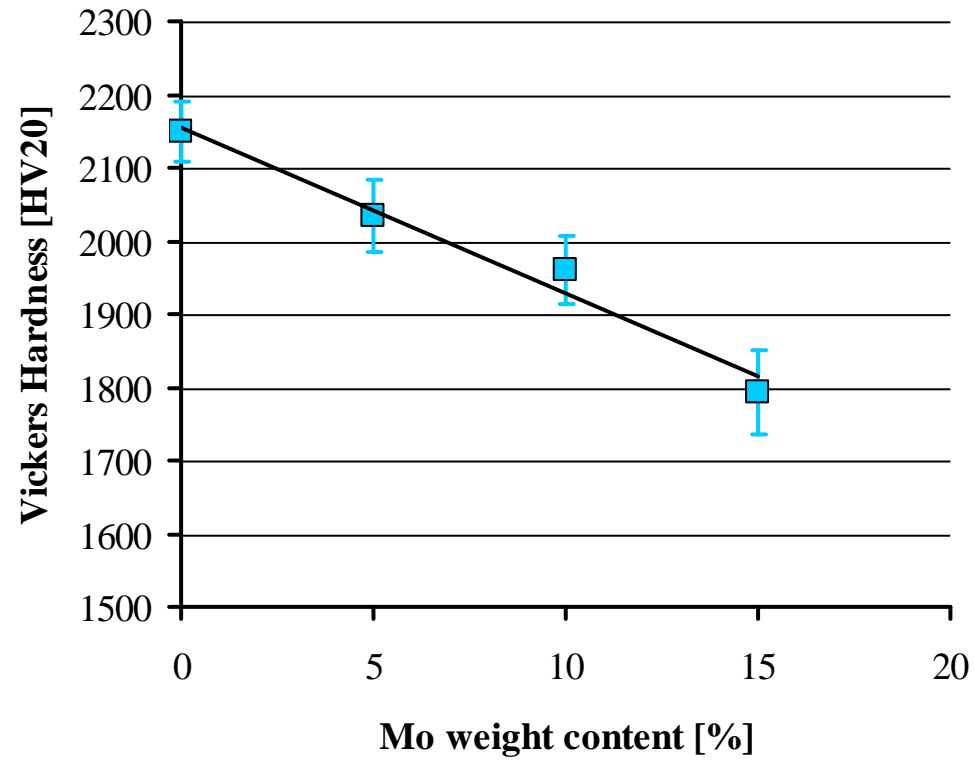

Figure 3. Results of Vickers hardness for produced $\mathrm{Si}_{3} \mathrm{~N}_{4}-\mathrm{x} \%$ wt. Mo composites

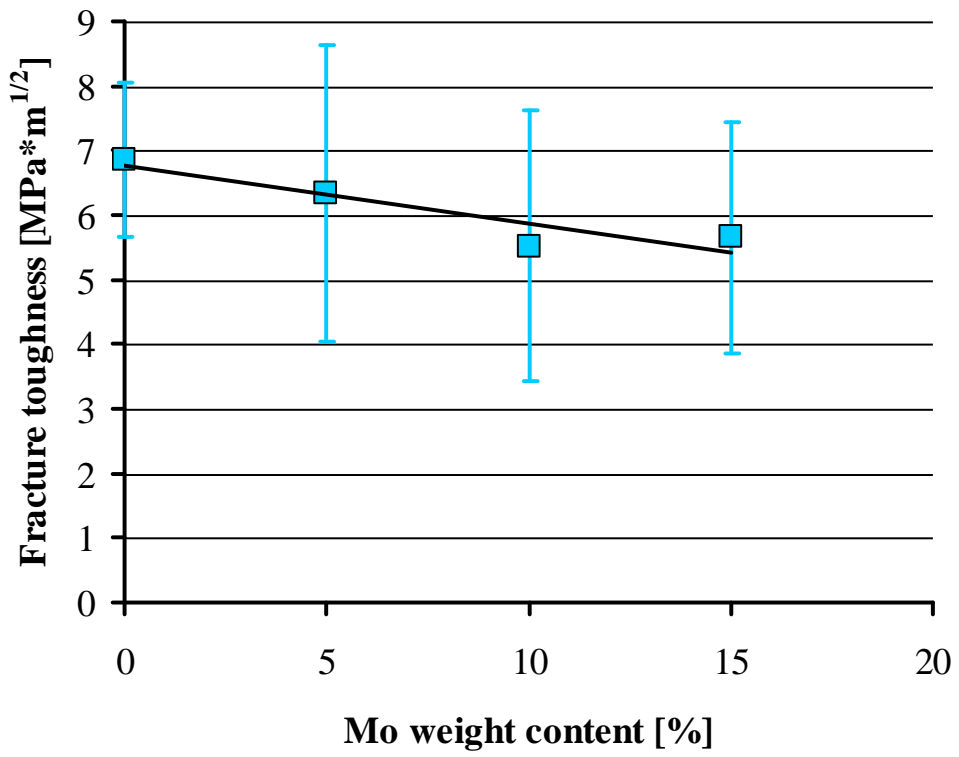

Figure 4. Fracture toughness results for produced $\mathrm{Si}_{3} \mathrm{~N}_{4}-\mathrm{X} \%$ wt. Mo composites 
Vickers hardness values decrease with the increase of molybdenum content in silicon nitride matrix (Fig. 3). Addition of 5 wt.\% of Mo phase results in over 5\% decrease in hardness compared to pure $\mathrm{Si}_{3} \mathrm{~N}_{4}$ sinter. The $\mathrm{Si}_{3} \mathrm{~N}_{4}-15 \%$ wt. $\%$ Mo composite is characterized with the lowest among all composites hardness value of 1794 HV20 which stand for a $16 \%$ decrease. Nonetheless the high hardness of silicon nitride matrix causes that even after an addition of molybdenum phase the hardness of produced silicon nitride-molybdenum composites stays at the high level - sufficient to be used as cutting tools in machining process of cast iron and even hardened steels.

Measured for produced composites values of average $\mathrm{K}_{\mathrm{IC}}$ coefficient are characterized with high standard deviation making it hard to properly interpret the results (Fig. 4). It is believed that high standard deviation is caused by presence of molybdenum silicides particles which are characterized with high brittleness at room temperature. It would explain a divergence between measurements because a fracture can propagate through brittle molybdenum silicide (lower value of $\mathrm{K}_{\mathrm{IC}}$ coefficient) particle or not (higher value of $\mathrm{K}_{\mathrm{IC}}$ coefficient). Especially when silicides are characterized with inhomogeneous distribution in silicon nitride matrix.

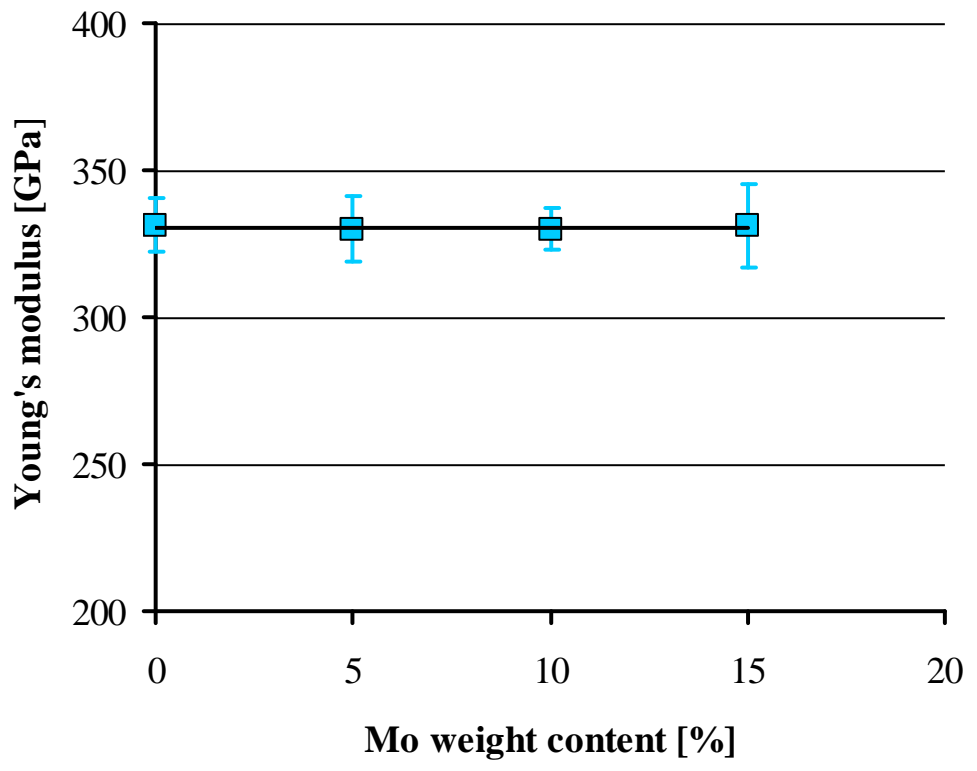

Figure 5. Young's modulus for produced $\mathrm{Si}_{3} \mathrm{~N}_{4}-\mathrm{X} \%$ wt. Mo composites

Young's modulus values of produced composites stay practically on the same level in spite of the various molybdenum content (Fig. 5).

Machining tests results for produced composites in which 145 CR6 stainless steel was used as the machined material resulted in very fast wear of cutting edges (1-2 min). That is why authors decided to use cast iron instead of stainless steel and the results presented below are focused on machining of GG FP cast iron.

Machining tests show that produced cutting tools are characterized with average cutting tool life of $5.5 \pm 0.1 \mathrm{~min}$ (Fig. 6). It's almost the same value that was achieved for commercial 
cutting tool $(5.4 \pm 0.2 \mathrm{~min})$ what is presented in Figure 8 . In both cases cutting tools edges wear is uniform and does not bear the traces of chipping or cracking. Surface roughness parameter $R a$ obtained for $\mathrm{Si}_{3} \mathrm{~N}_{4}-5 \%$ wt. Mo composite cutting tool is between $0.5-1.25 \mu \mathrm{m}$ (Fig. 7). During the $3^{\text {rd }}$ machining test slightly higher values of parameter $R a$ was observed. Surface roughness of cast iron after machining with commercial cutting tool equals 0.5$0.75 \mu \mathrm{m}$ (Fig. 9). The results for both produced and commercial cutting tools are very similar to each other what proofs that $\mathrm{Si}_{3} \mathrm{~N}_{4}-5 \%$ wt. Mo cutting tools are characterized with good machining performance.

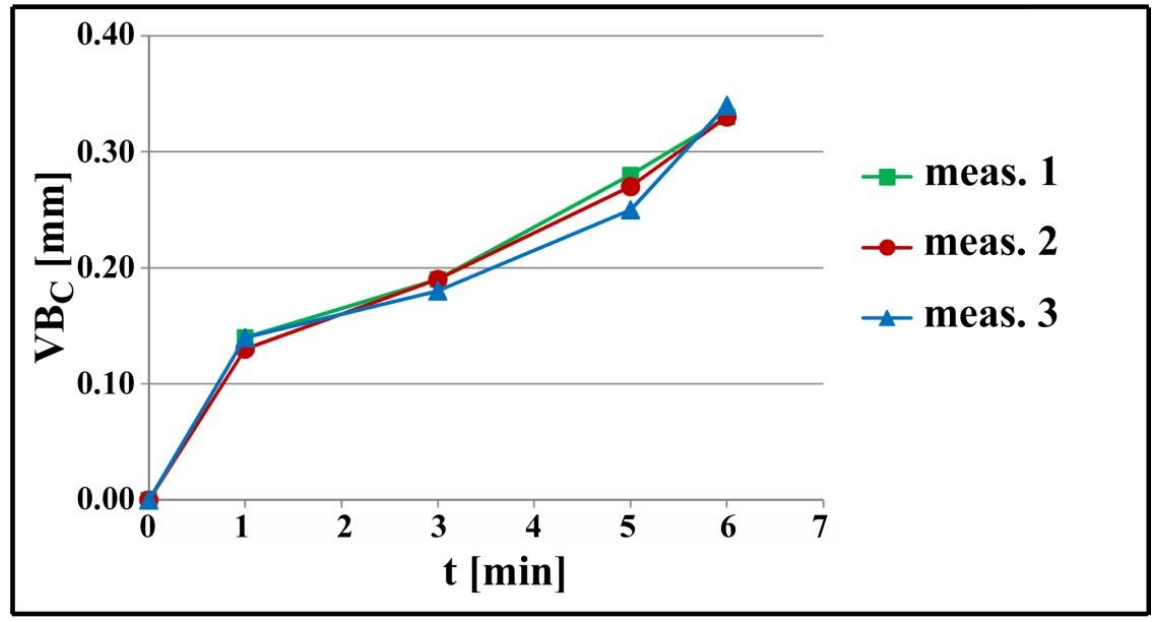

Figure 6. Machining tests results for $\mathrm{S}_{3} \mathrm{~N}_{4}-5 \%$ wt. Mo composite tool

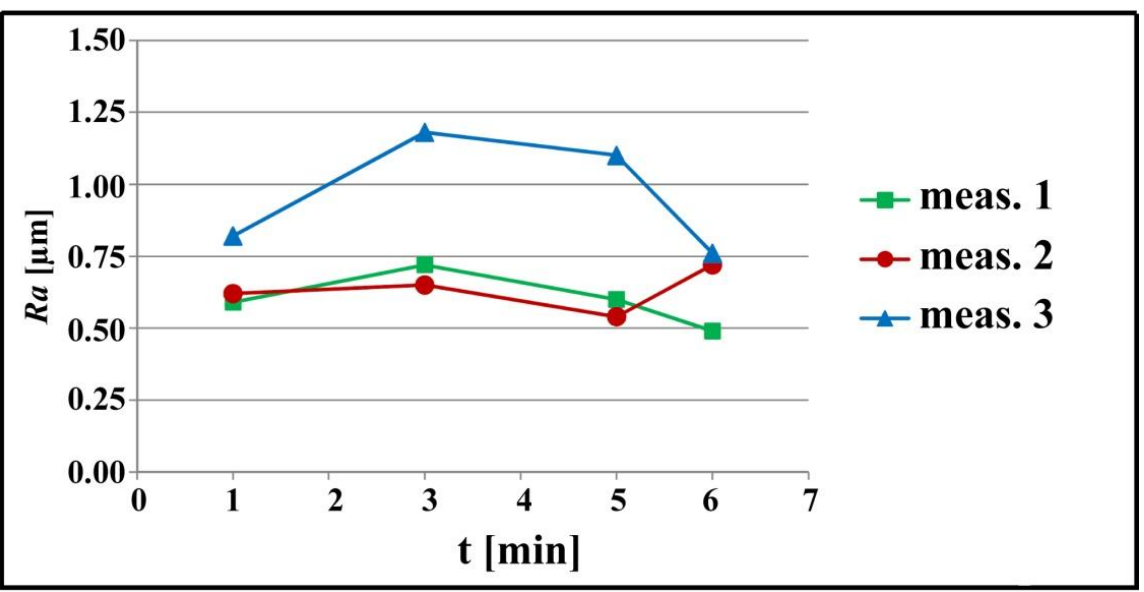

Figure 7. Surface roughness of GG FP cast iron results after machining using $\mathrm{S}_{3} \mathrm{~N}_{4}-5 \%$ wt. Mo composite tool 


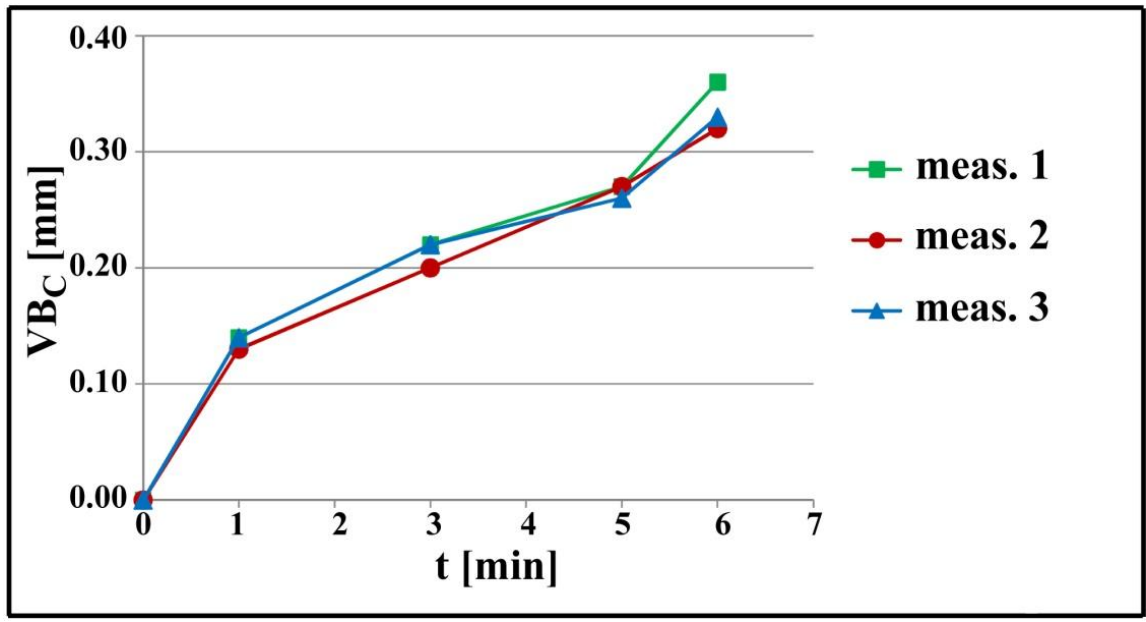

Figure 8. Machining test results for a commercial ceramic cutting tool

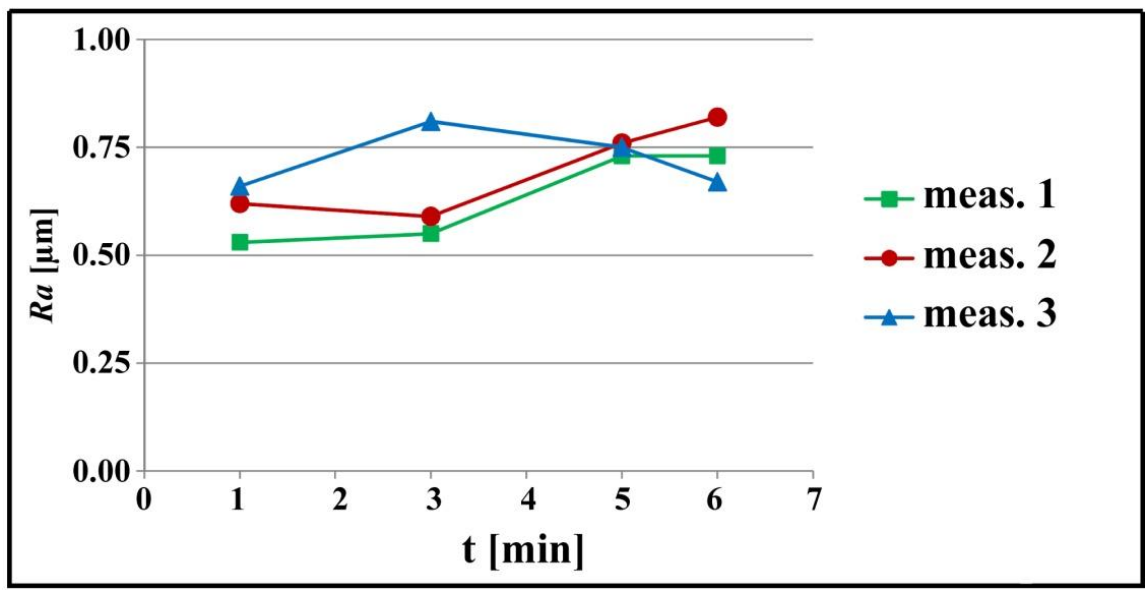

Figure 9. Surface roughness results for a commercial ceramic cutting tool

\section{SUMMARY}

The produced composites are characterized with near theoretical density.

Mechanical properties of produced composites are suitable for machining cast iron (high hardness and high fracture toughness).

Conducted dry machining tests showed that both composite cutting tools (produced and commercial) are characterized with almost the same cutting tool life parameter: 5.5 min and $5.4 \mathrm{~min}$.

Produced cutting tools wear was uniform without traces of chipping.

Obtained average surface roughness parameter $R a$ for both produced and commercial cutting tools was similar $0.5-0.75 \mu \mathrm{m}$ and $0.5-1.25 \mu \mathrm{m}$ respectively. 


\section{ACKNOWLEDGMENT}

Scientific research supported by Polish Ministry of Science and High Education (Grant No. 513G/1090/0738/101)

\section{LITERATURE}

[1] BOCANEGRA-BERNAL M.H., MATOVIC B., Mechanical properties of silicon nitride-based ceramics and its use structural application at high temperatures, Materials Science and Engineering A527, 2010, 1314-1338.

[2] BRONISZEWSKI K., WOŹNIAK J., CZECHOWSKI K., JAWORSKA L., OLSZYNA A., $\mathrm{Al}_{2} \mathrm{O}_{3}$ - $\mathrm{Mo}_{\mathrm{cutting}}$ tools for machining hardened stainless steel, Wear 303 (2013) 87-91.

[3] CHEN H., MA, Q., SHAO X., MA J., WANG C., HUANG B., Microstructure, mechanical properties and oxidation resistance of $\mathrm{Mo}_{5} \mathrm{~S}_{33}-\mathrm{Al}_{2} \mathrm{O}_{3}$ composite, Materials Science and Engineering A 592, 2014, 12-18.

[4] KRISHNARAO R.V., SUBRAHMANYAM J., Sintering of $\mathrm{MoSi}_{2}$ by reacting (Mo + Si $\left.i_{3} \mathrm{~N}_{4}\right)$ compacts, Materials Science and Engineering A352, 2003, 340-343.

[5] LUBE T., DANZER R., Advanced Ceramics for dentistry, Chapter 9 Mechanical properties and reliability of advanced ceramics, USA, Butterworth Heinemann, 2013, 173-199.

[6] MINGUELla J., CUINAS D., RODRIGUEZ J.V., VIVANCOS J., Advanced manufacturing of ceramics for biomedical applications: subjection methods for biocompatible materials, Procedia Engineering 63, 2013, 218224.

[7] OLSZYNA A. Ceramika Supertwarda, Warszawa, Oficyna Wydawnicza PW, 2011

[8] RICE R.W., Mechanical Properties of Ceramics and Composites, USA, Marcel Dekker Inc., 2000.

[9] SINGH S., GODKHINDI M.M., KRISHNARAO R.V., MURTY B.S., Synthesis of $\mathrm{Si}_{3} \mathrm{~N}_{4}-\mathrm{MoSi}_{2}$ in situ composite from mechanically activated $\left(\mathrm{Mo}+\mathrm{Si}_{3} \mathrm{~N}_{4}\right)$ powders, Journal of alloys and Compounds 381, 2004, 254-257. 